\title{
Therapeutic effects of tyroservatide on metastasis of lung cancer and its mechanism affecting integrin-focal adhesion kinase signal transduction
}

This article was published in the following Dove Press journal:

Drug Design, Development and Therapy

3 March 2016

Number of times this article has been viewed

Yu-ting Huangl,*

Lan Zhaol,*

Zheng Fu'

Meng Zhao'

Xiao-meng Song'

Jing Jia'

Song Wang'

Jin-ping $\mathrm{Li}^{\prime}$

Zhi-feng Zhu'

Gang Lin ${ }^{1,2}$

Rong Lu',2

Zhi Yao ${ }^{1,3}$

'Department of Immunology, Tianjin Medical University, Tianjin, ${ }^{2}$ Shenzhen Kangzhe Pharmaceutical Co., Ltd., Shenzhen, ${ }^{3}$ Key Laboratory of Immuno Microenvironment and Disease of the Educational Ministry of China, Tianjin Medical University, Tianjin, People's Republic of China

*These authors contributed equally to this paper

Correspondence: Zhi Yao

Department of Immunology, Tianjin

Medical University, 22 Qixiangtai Road,

Tianjin 300070, People's Republic

of China

Tel +862283336667

Email yaozhi@tijmu.edu.cn

Rong Lu

Shenzhen Kangzhe Pharmaceutical Co., Ltd., I I Langshan Road, Shenzhen

518029, Guangdong, People's Republic

of China

Tel +862258197951

Fax +86 2260368186

Email lu_rong@vip.sina.com
Fax +862260368186

Abstract: Tyroservatide (YSV) can inhibit the growth and metastasis of mouse lung cancer significantly. This study investigated the therapeutic effects of tripeptide YSV on metastasis of human lung cancer cells and explored its possible mechanism that affects integrin-focal adhesion kinase (FAK) signal transduction in tumor cells. YSV significantly inhibited the adhesion and the invasion of highly metastatic human lung cancer cell lines 95D, A549, and NCI-H1299. In addition, YSV significantly inhibited phosphorylation of FAK Tyr397 and FAK Tyr576/577 in the 95D, A549, and NCI-H1299 human lung cancer cells in vitro. And the mRNA level and protein expression of FAK in these human lung cancer cells decreased at the same time. YSV also significantly inhibited mRNA and protein levels of integrin $\beta 1$ and integrin $\beta 3$ in the 95D, A549, and NCI-H1299 human lung cancer cells. Our research showed that YSV inhibited adhesion and invasion of human lung cancer cells and exhibited therapeutic effects on metastasis of lung cancer.

Keywords: tyroservatide, integrin, focal adhesion kinase, FAK, MMP-2, MMP-9

\section{Introduction}

Tyroservatide (YSV, tyrosyl-seryl-valine, pTyr-Ser-Val- $\mathrm{NH}_{2}$ ) is a bioactive tripeptide of tyrosyl-seryl-valine. Its chemical structural formula is L-tyrosine-L-serine-L-valine, its molecular formula is $\mathrm{C}_{17} \mathrm{H}_{25} \mathrm{~N}_{3} \mathrm{O}_{6}$, and its molecular weight is $367.40 \mathrm{Da}$. YSV has been previously shown to have anti-tumor effects on Lewis lung carcinoma and human lung carcinoma A549. ${ }^{1,2}$ Lung cancer is currently the most prevalent malignant tumor worldwide, and has the fastest rising incidence and mortality rate compared to any other cancer. The high mortality of this disease is attributable to its local invasion and/or metastasis to distant organs. ${ }^{3,4}$ Thus, it is important to develop novel drugs that inhibit metastasis. In addition to markedly inhibiting lung metastasis in the mouse Lewis lung cancer spontaneous metastasis model and the orthotopic model of A549 human lung carcinoma, YSV also inhibited the proliferation and the adhesion of B16-F10 cells to Matrigel..$^{5}$ In this study, in vitro anti-metastasis effects of YSV on human lung cancer cell lines 95D, A549, and NCI-H1299 were assayed. A549 cell is an adenocarcinoma human alveolar basal epithelial cell, which could induce spontaneous lung metastasis in nude mice. ${ }^{6} \mathrm{NCI}-\mathrm{H} 1299$ cell is derived from the metastatic lymph node of lung carcinoma. ${ }^{7}$ 95D cells were subcloned from the PLA-801 human giant-cell lung carcinoma cell line in the People's Republic of China, which could induce spontaneous lung and lymph node metastasis. ${ }^{8}$

The metastasis of a malignant tumor is possible with the ability of invasion and adhesion of tumor cells. The dynamic regulation of adhesion is vital in the movement, metastasis, and invasion of tumor cells. ${ }^{9}$ The Matrigel invasion assays and

(c) (1) (2) 2016 Huang et al. This work is published and licensed by Dove Medical Press Limited. The full terms of this license are available at https://www.dovepress.com/terms.php
and incorporate the Creative Commons Atrribution - Non Commercial (unported, v3.0) License (http://creativecommons.org/licenses/by-nc/3.0/). By accessing the work you hereby accept the Terms. Non-commercial uses of the work are permitted without any further permission from Dove Medical Press Limited, provided the work is properly attributed. For permission for commercial use of this work, please see paragraphs 4.2 and 5 of our Terms (https://www.dovepress.com/terms.php). 
Transwell assays are the commonly used in vitro invasion assays, which are used to detect the inhibiting effect of YSV on invasion and adhesion of highly metastatic human lung cancer cells.

Extracellular matrix (ECM) degradation by tumor-derived proteinases plays an important role in tumor metastasis. The matrix metalloproteinases (MMPs) have the capacity to catalyze the degradation of structural ECM proteins in tumor cells. ${ }^{10,11}$ MMPs facilitate tumor cell invasion and metastasis by at least three distinct mechanisms: 1) by eradicating physical barriers to invasion through degradation of collagens, laminins, and proteoglycans in the ECM; 2) by modulating cell adhesion and enabling cells to form new cell-to-cell and cell-to-matrix attachments while breaking existing ones; and 3 ) by acting on ECM components and other proteins to expose hidden biological activities, such as release of angiostatin from plasminogen. ${ }^{12}$ As the neutral proteinases involved in the breakdown and remodeling of the ECM, MMP-2 and MMP-9 induce the degradation of the major element of ECM - collagen IV. ${ }^{13}$ The expression and activation of both MMP-2 and MMP-9 are influenced by focal adhesion kinase (FAK) signaling pathway. ${ }^{14,15} \mathrm{FAK}$ is a non-receptor protein tyrosine kinase which is recruited at an early stage to focal adhesions and is a key component of the signal transduction pathways triggered by integrins. ${ }^{16,17}$ Studies at the protein level consistently demonstrated that FAK overexpression as a neoplastic tissue developed the capacity for invasion and metastasis. In addition, FAK has been shown to be overexpressed in a variety of tumors, including breast, thyroid, ovarian, head and neck, and colon. ${ }^{18-21}$ In this study, gelatin zymography assay, Western blot, and realtime polymerase chain reaction (PCR) were used to detect the effect of YSV on activity and expression of MMP-2 and MMP-9 in three human lung cancer cells. Western blot and real-time PCR were applied for measuring phosphorylation of FAK Tyr397 and FAK Tyr576/577 in 95D, A549, and NCI-H1299 human lung cancer cells.

It has been reported that the activation of FAK is dependent on binding of upstream factor integrin to its ligand. Integrin-mediated FAK activation plays a critical role in the adhesion, invasion, and metastasis of tumor cells. Especially, integrins are crucial for tumor cell invasion and migration for sending and receiving molecular signals that regulate these processes. The intracellular signals mediated by $\beta 1$ and $\beta 3$ integrins are transferred from ECM to cells to induce the downstream reaction. ${ }^{22,23}$ In this study, expression of integrin $\beta 1$ and integrin $\beta 3$ proteins in the 95D, A549, and NCI-H1299 human lung cancer cells was examined by flow cytometry after YSV treatment, and mRNA levels of these two integrins were measured by real-time PCR.

\section{Materials and methods Reagents and antibodies}

The YSV peptide used in this study was custom-manufactured by Shenzhen Kangzhe Pharmaceutical Co., Ltd. (Shenzhen, People's Republic of China). All cell culture media and supplements were purchased from Thermo Fisher Scientific (Waltham, MA, USA). Chemical reagents were purchased from SigmaAldrich (St Louis, MO, USA), unless otherwise specified.

\section{Cell culture}

Ethics Committee approval was obtained from the Institutional Ethics Committee of Tianjin Medical University at the commencement of the study. The human lung cancer cell lines 95D, A549, and NCI-H1299 were cultured in RPMI 1640 supplemented with $10 \%$ fetal bovine serum in a humidified atmosphere of $5 \% \mathrm{CO}_{2}$ at $37^{\circ} \mathrm{C}$. The cells were routinely examined and found to be free of mycoplasma contamination.

\section{In vitro cell adhesion assay with Matrigel}

Trypan Blue is used for viable cell counting. The human lung cancer cell lines 95D, A549, and NCI-H1299 were pretreated with YSV $(0.1 \mathrm{mg} / \mathrm{mL}, 0.2 \mathrm{mg} / \mathrm{mL}, 0.4 \mathrm{mg} / \mathrm{mL}, 0.8 \mathrm{mg} / \mathrm{mL})$ for 24 hours, 48 hours, and 72 hours. Cells in YSV group were resuspended in $0.1 \%$ bovine serum albumin (BSA) RPMI 1640 (Thermo Fisher Scientific) at a final concentration of $5 \times 10^{5}$ cells $/ \mathrm{mL}$. The $0.1 \%$ BSA RPMI 1640 was used as negative control. A $0.1 \mathrm{~mL}$ aliquot of each cell suspension was placed into six cells of a 96-well culture plate coated with $0.2 \mathrm{mg} / \mathrm{mL}$ Matrigel (Becton Dickinson, Franklin Lakes, NJ, USA). The cells were then incubated for 1 hour at $37^{\circ} \mathrm{C}$ in $5 \%$ $\mathrm{CO}_{2}$. At the end of incubation, cells that had not adhered to Matrigel were washed away with phosphate-buffered saline (PBS). Optical density (OD) was measured by MTS assay at a wavelength of $492 \mathrm{~nm}$, and the adhesion inhibition rate (\%) was calculated according to the following formula:

Adhesion $=1-\frac{\text { Mean OD value of the treatment group }}{\text { Mean OD value of the control group }} \times 100$.

\section{In vitro invasion assay with Matrigel}

Transwell chambers (6.5 $\mathrm{mm}$ in diameter, $8 \mu \mathrm{m}$ pore size) were obtained from Corning Costar (Cambridge, MA, USA). The lower sides of polycarbonate filters with $8 \mu \mathrm{m}$ pores were coated with fibronectin (Becton Dickinson), and the upper 
sides were coated with Matrigel $(0.2 \mathrm{mg} / \mathrm{mL})$. The filters were dried and placed into the Transwell chambers. The 95D, A549, and NCI-H1299 cells were pretreated with YSV $(0.2 \mathrm{mg} / \mathrm{mL}$, $0.4 \mathrm{mg} / \mathrm{mL}$ ) for 48 hours. Each cell group was resuspended in $0.1 \%$ BSA RPMI 1640 at a final concentration of $2 \times 10^{6}$ cells $/ \mathrm{mL}$. One hundred microliters of each cell suspension was placed into three upper chamber wells. The lower chamber wells were filled with $600 \mu \mathrm{L}$ of $0.1 \%$ BSA RPMI 1640. The chambers were incubated for 4 hours at $37^{\circ} \mathrm{C}$ in $5 \% \mathrm{CO}_{2}$. At the end of incubation, cells that remained on the upper surface of the filter were gently removed with a cotton swab. Cells that had migrated to the lower surface of the filter were stained with hematoxylin and eosin and counted under a microscope. The number of the cells in five fields were counted (magnification: $\times 400)$, and the invasion inhibition rate (\%) was calculated according to the following formula:

Invasion $=1-\frac{\text { Mean number of invasive cells in the treatment group }}{\text { Mean number of invasive cells in the control group }} \times 100$. rate (\%) $=1-\frac{\text { Mean number of invasive cells in the control group }}{\text { (2) }}$

\section{SDS-PAGE gelatin zymography}

Sodium dodecyl sulfate polyacrylamide gel electrophoresis (SDS-PAGE) gelatin substrate zymography was used to analyze enzymatic activity of MMP-2 and MMP-9. After pretreated with YSV $(0.2 \mathrm{mg} / \mathrm{mL}, 0.4 \mathrm{mg} / \mathrm{mL})$ for 48 hours, culture media of 95D, A549, and NCI-H1299 cells were loaded onto a $10 \%$ acrylamide gel containing $1 \mathrm{mg} / \mathrm{mL}$ gelatin. After electrophoresis, gels were washed twice with $2.5 \%$ Triton X-100 for 30 minutes at room temperature to remove SDS followed by washing twice with $50 \mathrm{mM}$ Tris$\mathrm{HCl}$ buffer for 30 minutes to recover enzyme activity, and then incubated in MMP developing buffer (50 mM Tris, $40 \mathrm{mM} \mathrm{HCl}, 200 \mathrm{mM} \mathrm{NaCl}, 5 \mathrm{mM} \mathrm{CaCl}_{2}$, and $0.2 \%$ Brij) at $37^{\circ} \mathrm{C}$ for 24 hours on a gyratory shaker. To visualize gelatin lysis, gels were then stained with Coomassie blue and destained with ethanol:acetic acid:water (15:5:30). Areas containing gelatinolytic activity appeared as clear white zones on the blue-stained background. To obtain quantitative information, the areas containing gelatinolytic activity were analyzed in a Phosphoimager (Amersham Biosciences, Piscataway, UK). Calculated values were normalized with the numbers of corresponding cells in each culture.

\section{Reverse transcription and real-time RT-PCR}

After pretreated with YSV $(0.2 \mathrm{mg} / \mathrm{mL}, 0.4 \mathrm{mg} / \mathrm{mL})$ for 48 hours, total RNA was extracted from cell lines 95D, A549, and NCI-H1299 with Trizol reagent (Thermo Fisher Scientific). First-strand cDNA synthesis was performed using $2 \mu \mathrm{g}$ total RNA, $500 \mathrm{ng}$ oligo(dT)18, and M-MLV Reverse Transcriptase (Promega Corporation, Fitchburg, WI, USA) under the conditions recommended by the supplier. The mRNA expression levels of MMP-2, MMP-9, FAK, integrin $\beta 1$, and integrin $\beta 3$ were quantified by quantitative real-time PCR using an ABI Prism 7500 Sequence Detection System and SYBR Green Real-Time Master Mix. The primers for amplification of target genes using realtime quantitative PCR were selected as follows: MMP-2

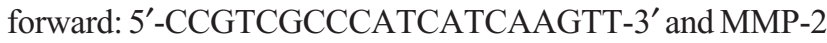
reverse: 5'-CTGTCTGGGGCAGTCCAAAG-3'; MMP-9 forward: 5'-GTGCTGGGCTGCTGCTTTGCTG-3' and MMP-9 reverse: 5'-GTCGCCCTCAAAGGTTTGGAAT-3'; FAK forward: 5'-TTCAAGAAGCCTTAACAATGCGT-3' and FAK reverse: 5'-CAGCTCCATGATTATCCAGACAG-3'; integrin $\beta 1$ forward: 5'-CAAGCAGGGCCAAATTGTGG-3' and integrin $\beta 1$ reverse: $5^{\prime}$-CCTTTGCTACGGTTGGTTA CATT-3'; integrin $\beta 3$ forward: 5'-AGAGCCAGA GTGTCCCAAG-3' and integrin $\beta 3$ reverse: 5'-GGCCTCTTTATACAGTGGGTTGT-3'; and $\beta$-actin forward: 5'-TTGCCGACAGGATGCAGAAGGA-3' and $\beta$-actin reverse: $5^{\prime}$-AGGTGGACAGCGAGGCCAGGAT-3'. The $\beta$-actin gene was used as an internal reference, normalizing the amplified target gene cDNA to amplified $\beta$-actin in order to compensate for any changes caused by RNA degradation or amplification efficiency. The reaction mixture was incubated at $95^{\circ} \mathrm{C}$ for 1 minute followed by 40 amplification cycles with the following conditions: 15 seconds at $95^{\circ} \mathrm{C}$, 15 seconds at $57^{\circ} \mathrm{C}$, and 45 seconds at $72^{\circ} \mathrm{C}$. The fluorescence signal was collected at every extension stage $\left(72^{\circ}\right)$. The relative expression of a target gene was calculated as described previously. ${ }^{24}$

\section{Western blot}

After pretreated with YSV $(0.2 \mathrm{mg} / \mathrm{mL}, 0.4 \mathrm{mg} / \mathrm{mL})$ for 48 hours, cell protein extracts were prepared by lysing cells for 20 minutes on ice in an Radioimmunoprecipitation assay (RIPA) lysis buffer consisting of $150 \mathrm{mmol} / \mathrm{L} \mathrm{NaCl}, 0.5 \%$ sodium deoxycholate, 1\% Nonidet P-40, 1\% Triton X-100, $1 \%$ SDS, and protease inhibitor cocktail (Sigma-Aldrich). The cell debris was removed by centrifugation at $15,000 \times g$ for 10 minutes at $4^{\circ} \mathrm{C}$. Then, cell extracts were subjected to separation by SDS-PAGE after being boiled in Laemmli buffer and then transferred to polyvinylidene difluoride (PVDF) membrane. The membrane was blocked with PBS containing $0.1 \%$ Tween 20 and 5\% non-fat milk before being incubated with the appropriate primary and secondary antibodies. Membranes were incubated with 1:1,000 antihuman MMP-2 antibody 
(R\&D Systems, Inc., Minneapolis, MN, USA), or 1:1,000 antiMMP-9 antibody (Chemicon, Temecula, CA, USA), or 1:6,000 anti- $\beta$-actin clone AC-15 (Sigma-Aldrich), or 1:1,000 anti-FAK (pY397) phosphospecific antibody (Biosource, Camarillo, CA, USA), or 1:1,000 anti-phospho-FAK (Tyr576/577) antibody (Cell Signaling Technology, Boston, MA, USA), or 1:1,000 anti-FAK antibody (Cell Signaling Technology) for 3 hours at room temperature, followed by incubation with 1:10,000 goat anti-mouse IgG horse radish peroxidase conjugate antibody or 1:10,000 goat anti-rabbit IgG horse radish peroxidase conjugate antibody (Upstate, Lake Placid, NY, USA) for 1 hour. The bound antibodies were visualized by using LumiGLO Chemiluminescent Substrate Kit (KPL, Gaithersburg, MD, USA). The products are reported as the target gene/ $\beta$-actin densitometric ratio calculated by the TotalLab software to compute the relative expression of proteins.

\section{Flow cytometry}

Following treatment with YSV $(0.2 \mathrm{mg} / \mathrm{mL}, 0.4 \mathrm{mg} / \mathrm{mL})$ for 48 hours, 95D, A549, and NCI-H1299 cells were harvested and detected by flow cytometry for integrin $\beta 1$ and integrin $\beta 3$ on the cell membrane. Briefly, cells were resuspended at a concentration of $1 \times 10^{6}$ cells $/ \mathrm{mL}$ in PBS. Integrin $\beta 1$ mouse monoclonal antibody or integrin $\beta 3$ mouse monoclonal antibody (Santa Cruz Biotechnology Inc., Dallas, TX, USA) was added to cells to a final concentration recommended by the supplier before being incubated at $37^{\circ} \mathrm{C}$ with $5 \% \mathrm{CO}_{2}$ for 1 hour. Then, fluorescein isothiocyanate-conjugated secondary antibody was added to cell suspensions. After incubated at $37^{\circ} \mathrm{C}$ with $5 \% \mathrm{CO}_{2}$ for another 1 hour, the cells were washed three times with PBS, and the mean fluorescence intensities of cells were detected by flow cytometry (FACS Calibur, Becton Dickinson, San Jose, CA, USA) with an excitation wavelength of $488 \mathrm{~nm}$ and an emission wavelength of $535 \mathrm{~nm}$.

\section{Statistical analysis}

Data were expressed as mean \pm standard deviation. Significance was tested using one-way analysis of variance followed by the Student-Newman-Keuls test (SPSS 11.0 software, Chicago, IL, USA). Significance was set at $P<0.05$.

\section{Results}

\section{YSV inhibited the adhesion of human lung cancer cells in vitro}

Matrigel is a gelatinous protein mixture secreted by Engelbreth-Holm-Swarm mouse sarcoma cells, which is rich in laminin and collagen IV. This mixture resembles the complex extracellular environment found in many tissues. One important application of Matrigel is in the evaluation of anti-metastasis drugs. The number of cells that adhere to Matrigel is the reflection of adhesive ability of tumor cells. After pretreatment with different doses $(0.1 \mathrm{mg} / \mathrm{mL}, 0.2 \mathrm{mg} / \mathrm{mL}$, $0.4 \mathrm{mg} / \mathrm{mL}, 0.8 \mathrm{mg} / \mathrm{mL}$ ) of YSV for 24 hours, 48 hours, and 72 hours, respectively, the ability of human lung cancer cells 95D, A549, and NCI-H1299 to adhere to Matrigel was obviously inhibited. The mean OD value of each YSV treatment group was significantly less than that of the control group in a dose- and time-dependent manner $(P<0.05)$. The optimized adhesion inhibition rates of the three lung cancer cell lines were $37.08 \%, 36.87 \%$, and $41.34 \%$, respectively (Figure 1).

\section{YSV inhibited the invasion of human lung cancer cells in vitro}

The most commonly used in vitro invasion assay is a modified Boyden chamber assay. Invasive cells that can degrade the Matrigel layer will migrate through the membrane and attach to the other side of the membrane. The number of invasive cells showed the invasive capacity of cells. Fewer cells from every YSV treatment group $(0.2 \mathrm{mg} / \mathrm{mL}, 0.4 \mathrm{mg} / \mathrm{mL})$ migrated to the lower surface of the filters than the control group. The differences between each YSV treatment group and the control group were significant $(P<0.05)$. The optimized invasive inhibition rates of the three lung cancer cell lines were $53.87 \%$, $62.10 \%$, and $64.44 \%$, respectively (Figure 2 ).

\section{YSV inhibited the expression and activity of MMP-2 and MMP-9}

The increase in the level of MMPs is positively related to enhanced tumor growth and metastasis. As the key enzymes to degrade the ECM, MMP-2 and MMP-9 are thought to be important in development of cancers, the formation of tumor blood vessels, and invasion and metastasis of tumors. ${ }^{25,26}$ Gelatin zymography analysis demonstrated that YSV $(0.2 \mathrm{mg} / \mathrm{mL}, 0.4 \mathrm{mg} / \mathrm{mL})$ significantly decreased the activities of MMP-2 and MMP-9 of 95D, A549, and NCI-H1299 cells after treatment for 48 hours $(P<0.05$, Figure $3 \mathrm{~A})$. Analysis also indicated that the YSV significantly inhibited mRNA and protein levels of MMP-2 and MMP-9 in lung cancer cells $(P<0.05$, Figure 3B, C and D).

\section{YSV inhibited the expression and activity of FAK in human cancer lung cells}

In this study, treatment with YSV $(0.2 \mathrm{mg} / \mathrm{mL}$ or $0.4 \mathrm{mg} / \mathrm{mL}$ ) significantly reduced the mRNA and protein levels in human lung cancer 95D, A549, and NCI-H1299 cells 

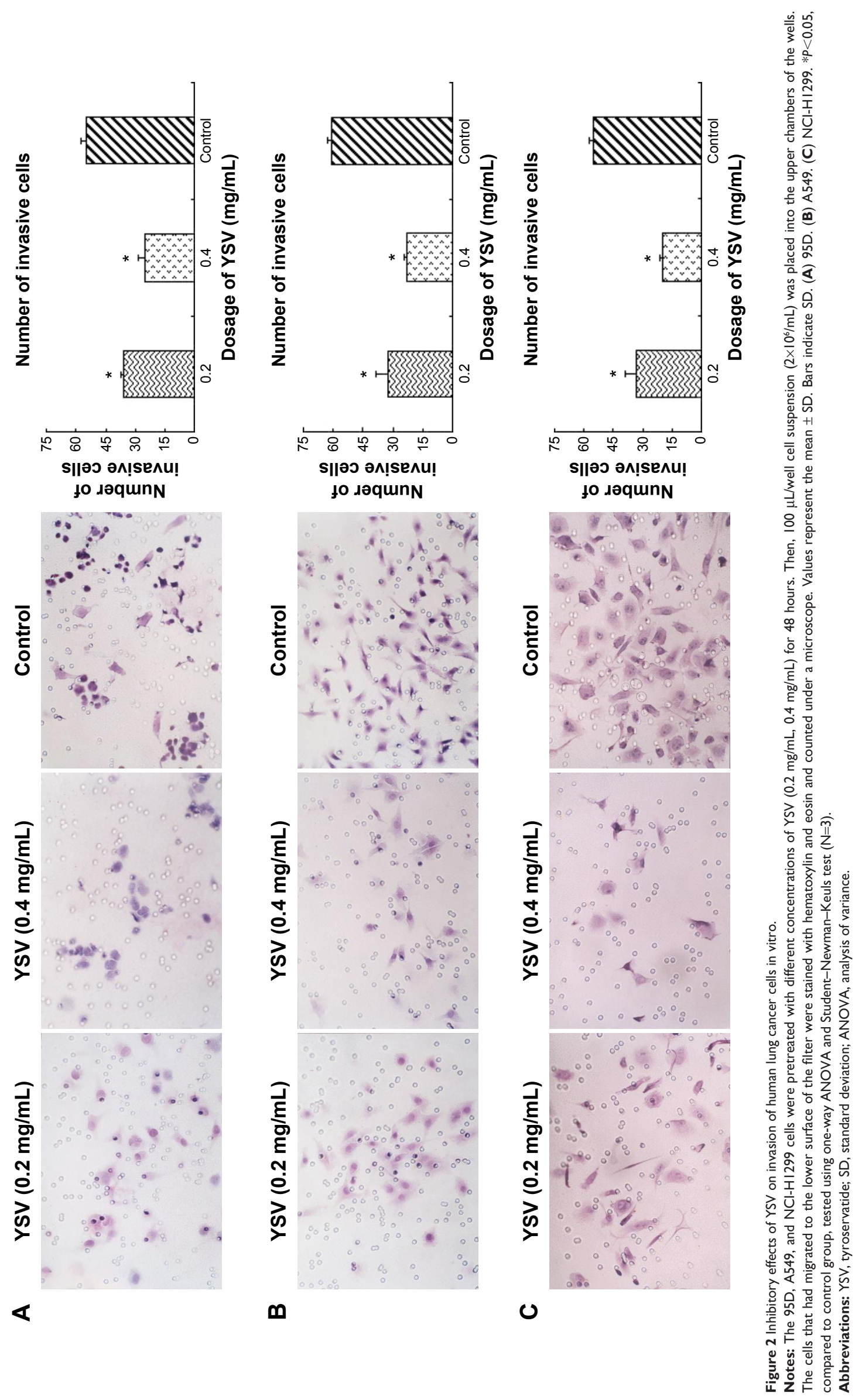
A
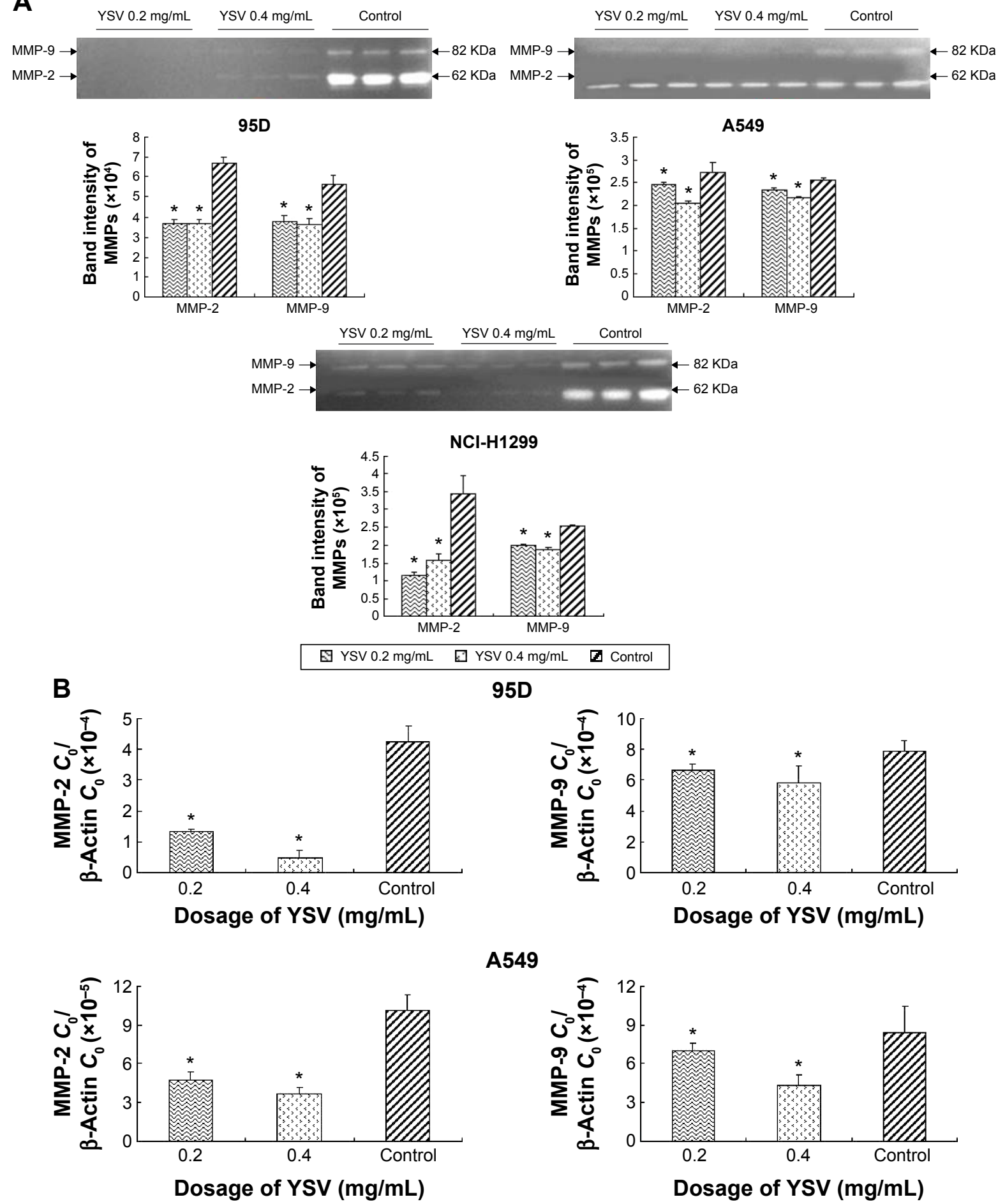

A549

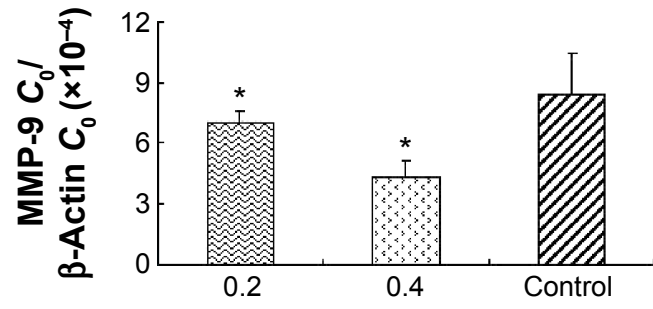

Dosage of YSV $(\mathrm{mg} / \mathrm{mL})$

NCl-H1299
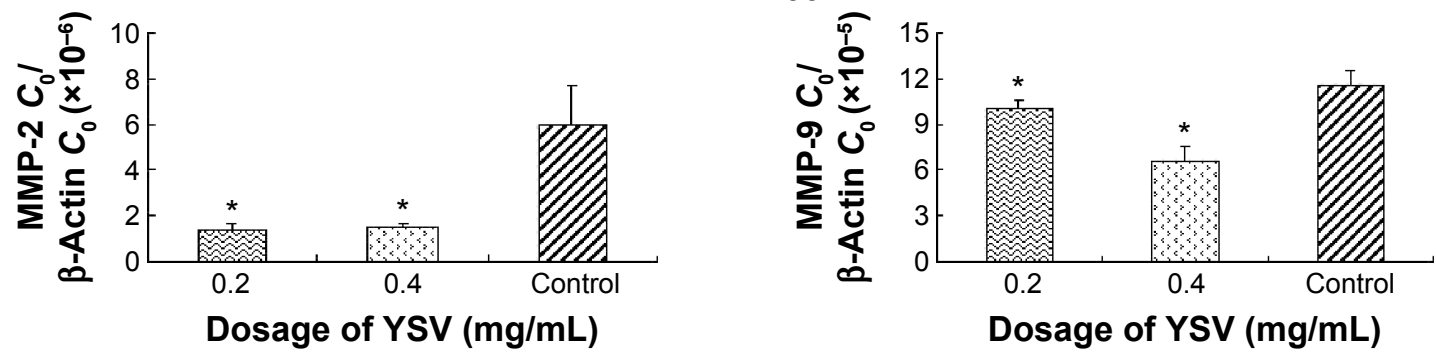

Figure 3 (Continued) 
C

MMP-2
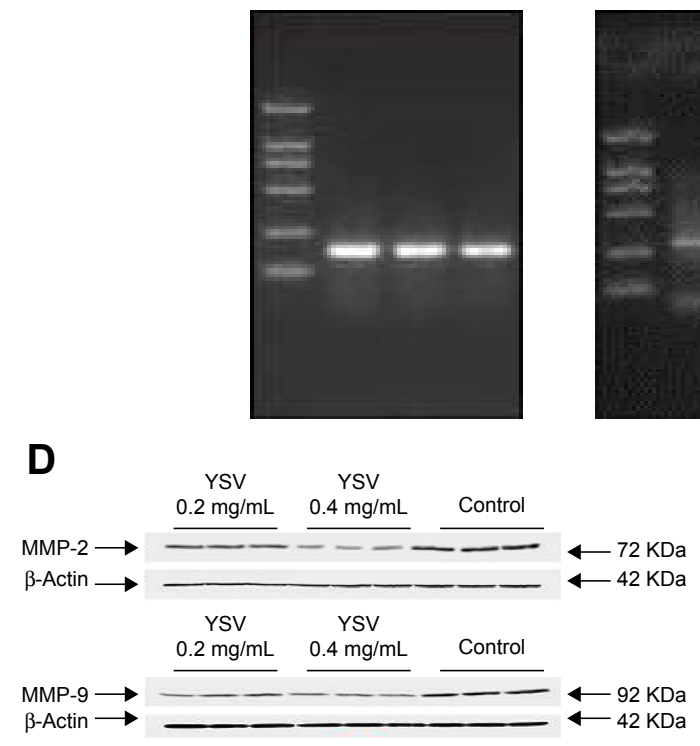

95D

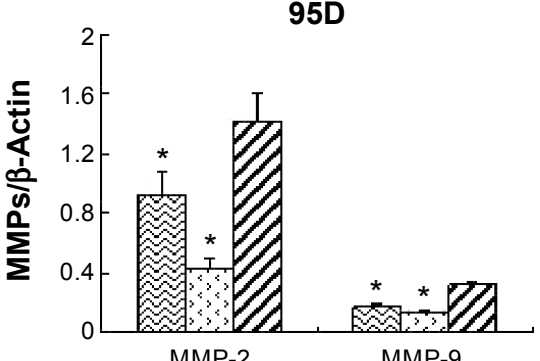

MMP-9

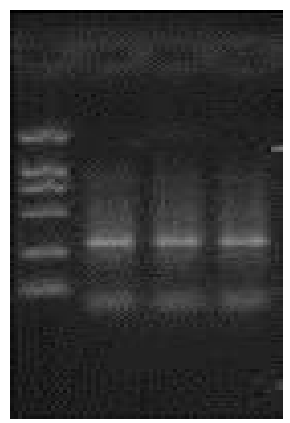

$\beta$-Actin
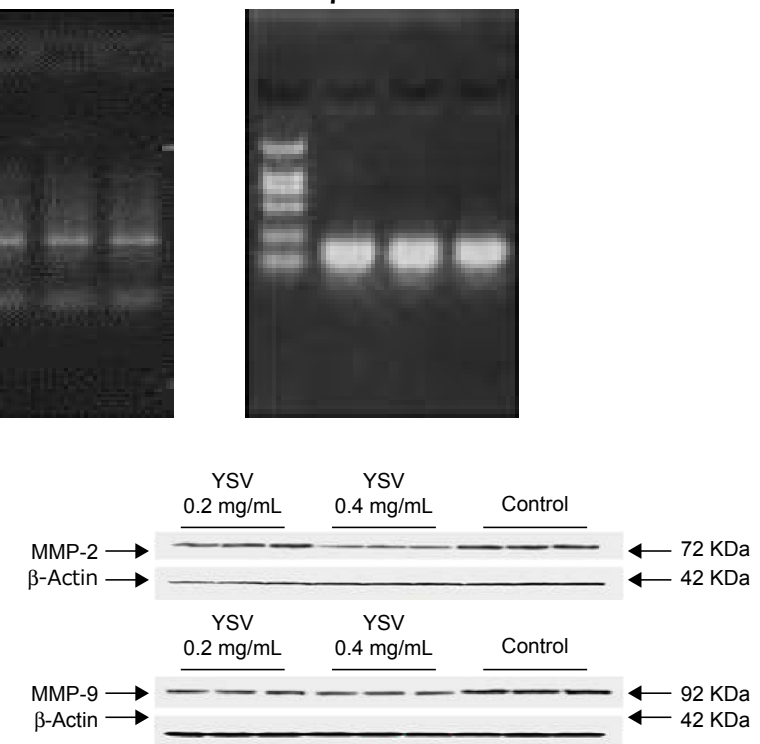

A549
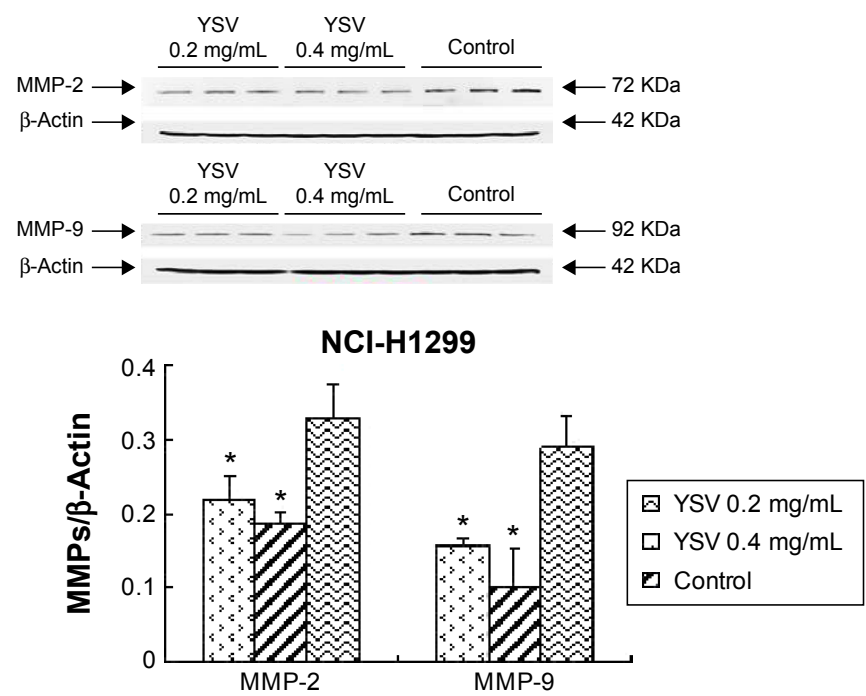

Figure 3 YSV inhibited the expression and activity of MMP-2 and MMP-9.

Notes: (A) Gelatin zymography assay for MMP-2 and MMP-9 activities from supernatant of 95D, A549, and NCl-HI299 cells after treated with YSV in vitro. Supernatants of lung cancer cells treated with different concentrations of YSV for 48 hours were collected and loaded onto $10 \%$ acrylamide (containing $0.1 \%$ gelatin) gels. After electrophoresis, the gels were washed, incubated, stained, and destained. Gelatinolytic activities were identified as clear bands on a background. The relative gelatinolytic activities of MMP-2 and MMP-9 were quantified densitometrically in relation to the activity without YSV. (B) Real-time PCR analysis of MMP-2 and MMP-9 mRNA levels in the 95D, A549, and NCI-HI299 cells after treated with YSV in vitro. Real-time PCR was performed on total RNA for detection of mRNA level of MMP-2 and MMP-9. The products were quantified using $\beta$-actin as an internal reference. (C) $2 \%$ agarose gel electrophoresis of real-time PCR production. (D) Western blot analysis of the levels of MMP-2 and MMP-9 in the 95D, A549, and NCl-HI 299 cells after treated with YSV in vitro. Total proteins of lung cancer cells treated with different concentrations of YSV for 48 hours were extracted and separated by SDS-PAGE. After electrophoresis, the protein was transferred to PVDF membrane, and detection was performed with antibodies against target proteins. The products are reported as the target protein/ $\beta$-actin densitometric ratio calculated by the TotalLab software to compute the relative expression of proteins. $* P<0.05$, compared to control group, tested using one-way ANOVA and Student-Newman-Keuls test $(\mathrm{N}=3)$.

Abbreviations: YSV, tyroservatide; MMP, matrix metalloproteinase; PVDF, polyvinylidene difluoride; PCR, polymerase chain reaction; SDS-PAGE, sodium dodecyl sulfate polyacrylamide gel electrophoresis; ANOVA, analysis of variance. 
A
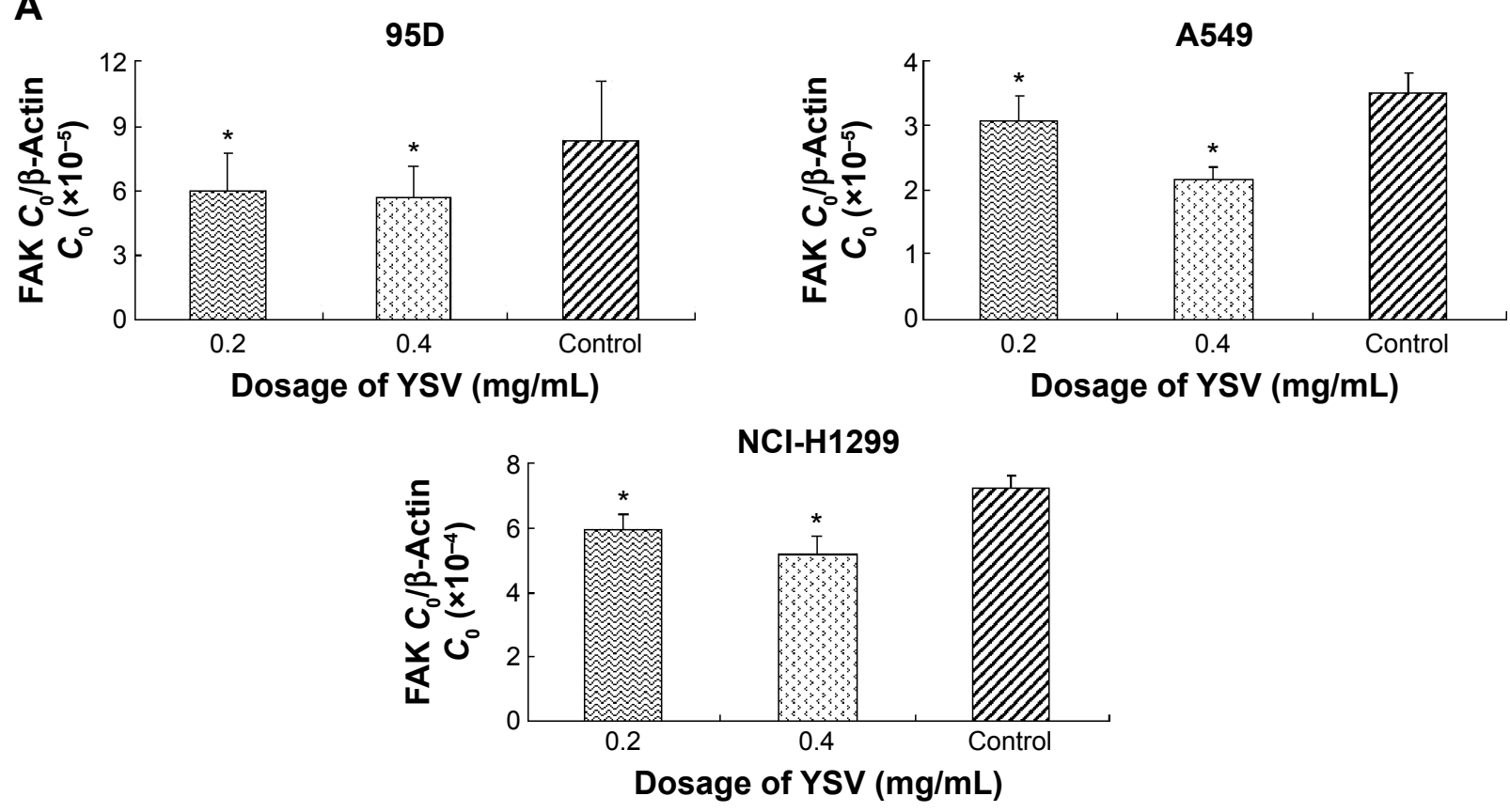

B
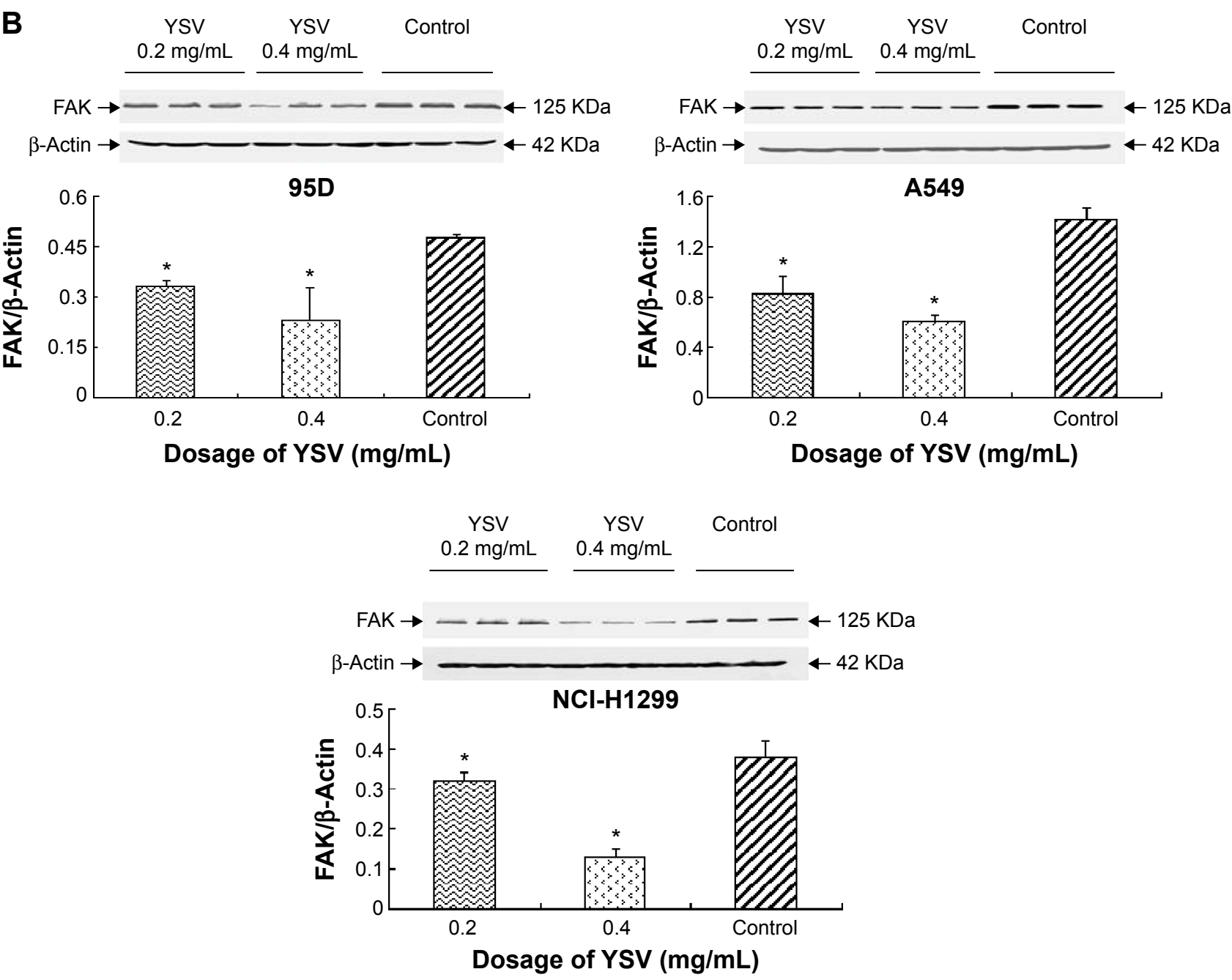

Figure 4 (Continued) 

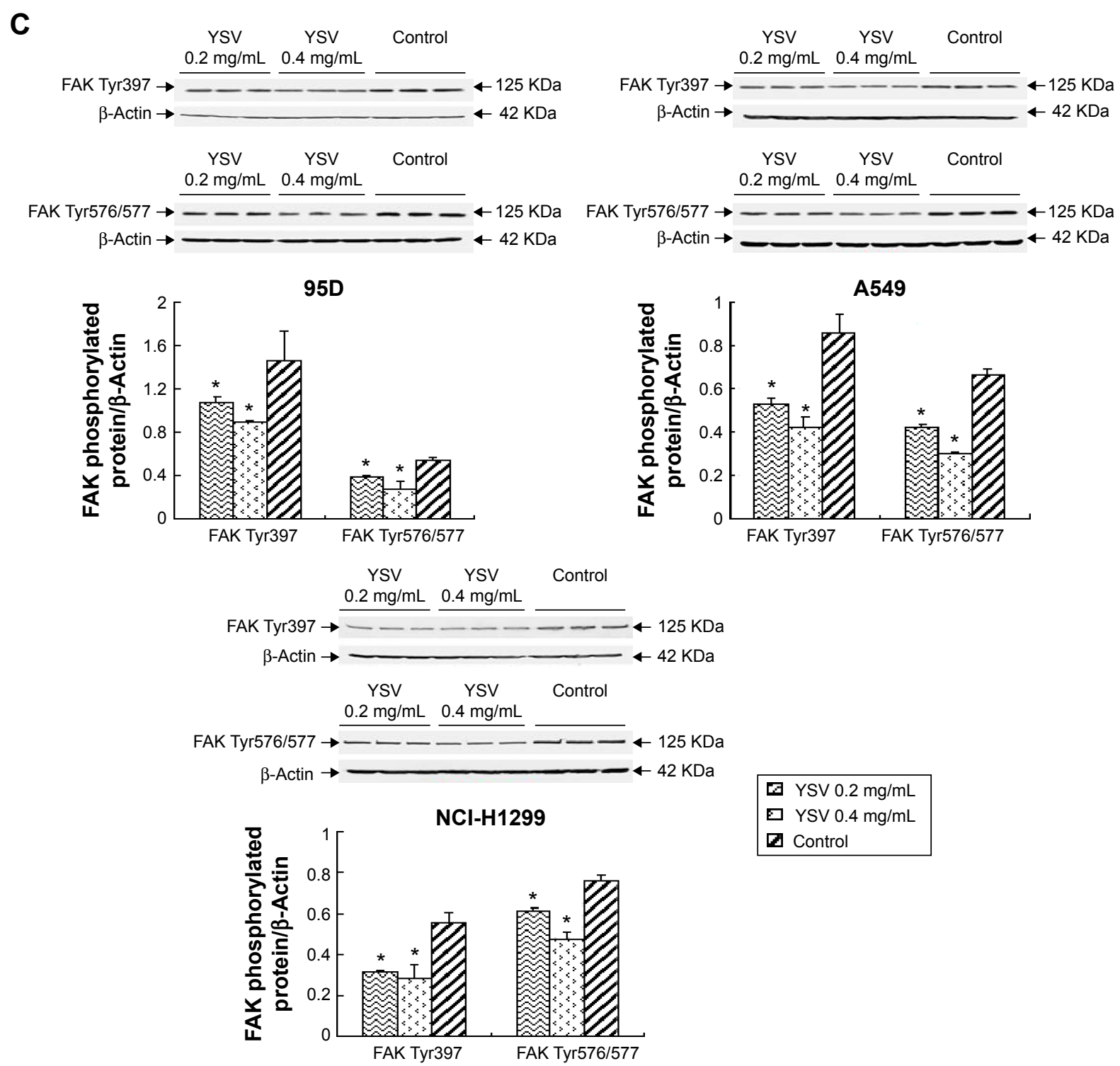

Figure 4 YSV inhibited the expression and activity of FAK in human cancer lung cells.

Notes: (A) Real-time PCR analysis of FAK mRNA level in the 95D, A549, and NCl-HI 299 cells after treated with YSV in vitro. Real-time PCR was performed on total RNA for detection of FAK mRNA level. The products were quantified using $\beta$-actin as an internal reference. (B) Western blot for FAK in the 95D, A549, and NCI-HI299 cells after treated with YSV in vitro. Total proteins of 95D, A549, and NCl-HI 299 cells treated with different concentrations of YSV for 48 hours were extracted and separated by SDSPAGE. After electrophoresis, the protein was transferred to PVDF membrane, and detection was performed with antibody against target protein. The products are reported as the target protein/ $\beta$-actin densitometric ratio calculated by the TotalLab software to compute the relative expression of proteins. (C) Western blot for phosphorylation of FAK Tyr397 and Tyr576/577 in the 95D, A549, and NCl-HI299 cells after treated with YSV in vitro. Total proteins of 95D, A549, and NCl-HI299 cells treated with different concentrations of YSV for 48 hours were extracted and separated by SDS-PAGE. After electrophoresis, the protein was transferred to PVDF membrane, and detection was performed with antibody against target protein. The products are reported as the target protein/ $\beta$-actin densitometric ratio calculated by the TotalLab software to compute the relative expression of proteins. $* P<0.05$, compared to control group, tested using one-way ANOVA and Student-Newman-Keuls test ( $N=3$ ).

Abbreviations: YSV, tyroservatide; FAK, focal adhesion kinase; PCR, polymerase chain reaction; SDS-PAGE, sodium dodecyl sulfate polyacrylamide gel electrophoresis; PVDF, polyvinylidene difluoride; ANOVA, analysis of variance.

\section{YSV inhibited expression of integrin $\beta$ I and $\beta 3$ in lung cancer cells}

Integrins are $\alpha / \beta$ heterodimeric cell surface receptors that play a pivotal role in cell adhesion and migration, as well as in growth and survival. ${ }^{32}$ Integrins not only transmit signals to cells in response to the extracellular environment (outside-in signaling) but also sense intracellular cues to alter their interaction with extracellular environment (inside-out signaling). ${ }^{33}$ The interaction of activated integrins with ECM proteins induces cell surface integrin clustering at focal sites of the plasma membrane (known as focal adhesion plaques [FAPs]), a process driven from within the cell. ${ }^{34}$ These FAPs are composed of cytoskeletal proteins ( $\alpha$-actinin, talin, vinculin, paxillin, and tensin being a few representative ones) 
A

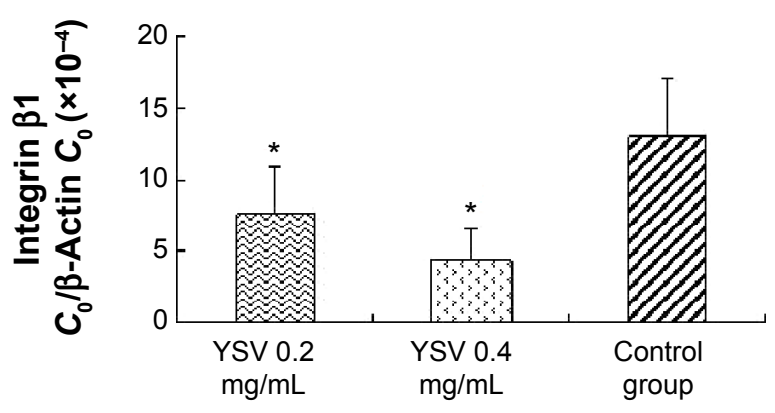

95D

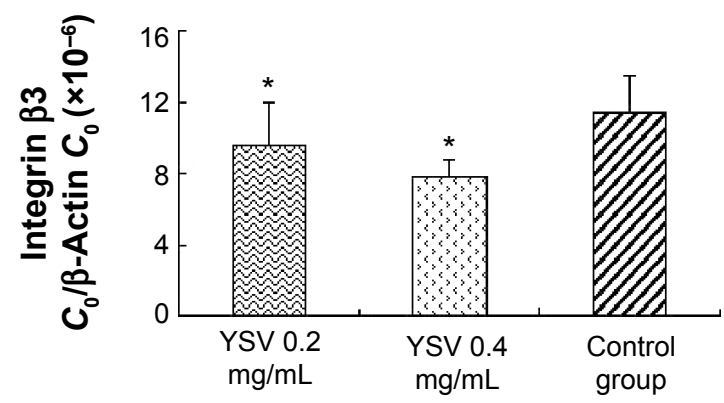

B

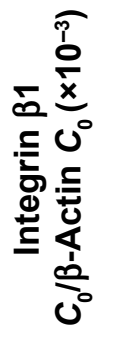

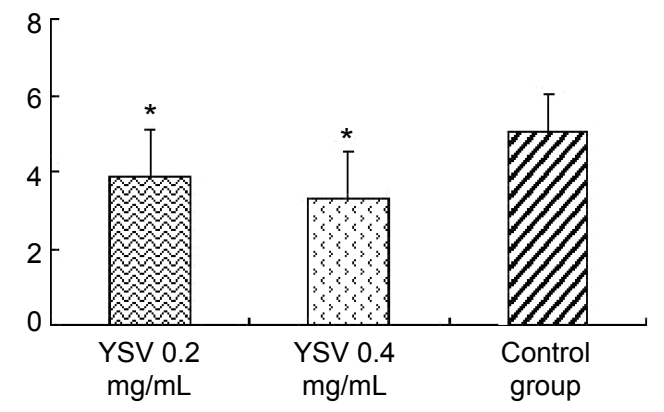

A549

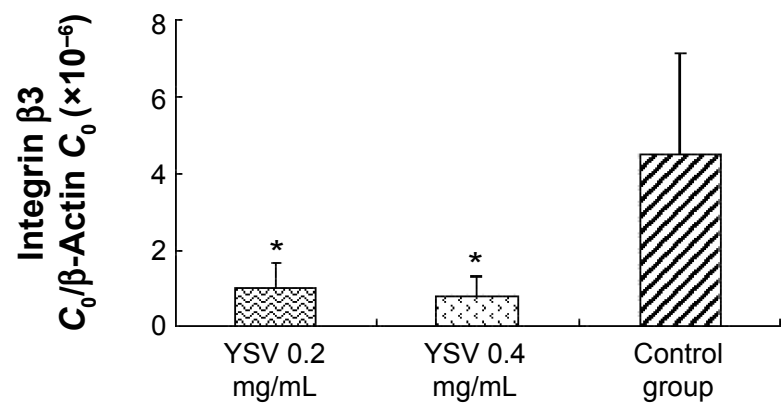

C

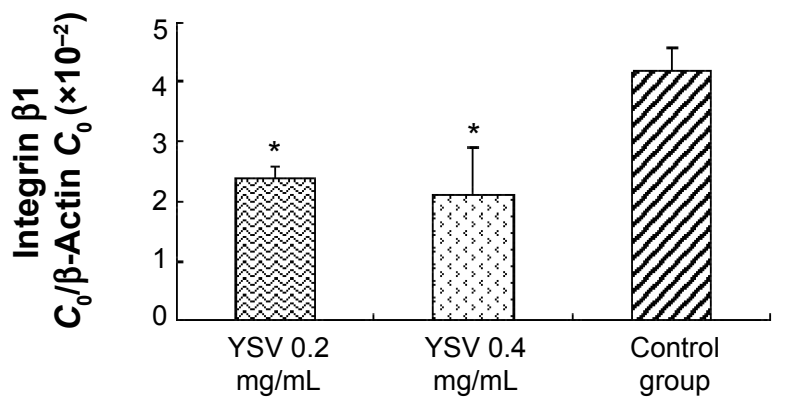

NCl-H1299

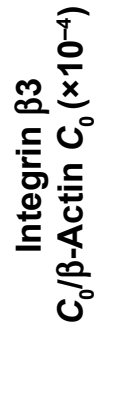

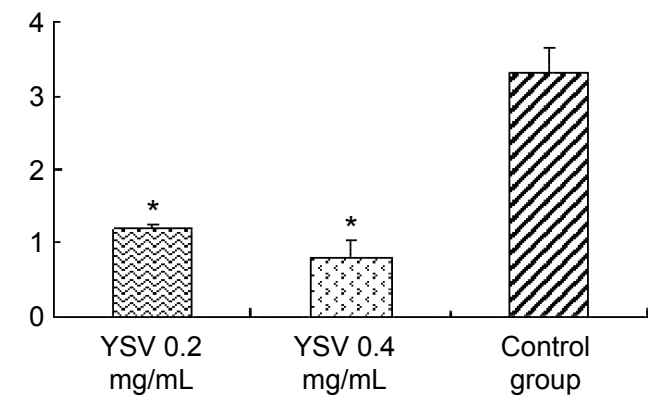

Figure 5 Real-time PCR analysis of mRNA level of integrin $\beta$ I and integrin $\beta 3$ in the 95D, A549, and NCl-HI299 cells after treated with YSV in vitro.

Notes: Real-time PCR was performed on total RNA for detection of mRNA level of integrin $\beta I$ and integrin $\beta 3$. The products were quantified using $\beta$-actin as an internal reference. (A) mRNA level of integrin $\beta I$ and integrin $\beta 3$ in 95D cells. (B) mRNA level of integrin $\beta I$ and integrin $\beta 3$ in A549 cells. (C) mRNA level of integrin $\beta I$ and integrin $\beta 3$ in $\mathrm{NCl}-\mathrm{HI} 299$ cells. $* P<0.05$, compared to control group, tested using one-way ANOVA and Student-Newman-Keuls test ( $\mathrm{N}=3$ ).

Abbreviations: PCR, polymerase chain reaction; YSV, tyroservatide; ANOVA, analysis of variance.

and signaling molecules (calreticulin, FAK, and cadherinassociated substrate). ${ }^{35}$ Following inside-out activation, integrin occupation and clustering at FAPs elicit outside-in signaling from the ECM into the cell cytoplasm that leads to cell migration, proliferation, differentiation, and survival. ${ }^{9}$ In this process, integrins $\beta 1$ and $\beta 3$ are critical factors for the formation of FAP and activation of FAK. ${ }^{16}$ Our results showed that YSV $(0.2 \mathrm{mg} / \mathrm{mL}, 0.4 \mathrm{mg} / \mathrm{mL})$ significantly decreased the mRNA and protein levels of integrins $\beta 1$ and $\beta 3$ in 95D, A549, and NCI-H1299 cells $(P<0.05$, Figures 5 and 6).

\section{Discussion}

Metastasis is a complicated procedure involving lots of steps. In brief, a metastatic cancer cell must escape from the primary tumor, enter the circulation, arrest the microcirculation, invade a different tissue compartment, and then grow at that secondary site. The invasion and adhesion of tumor cells are the key events of cancer metastasis. YSV significantly inhibited the adhesion of human lung cancer cells 95D, A549, and NCI-H1299 to Matrigel in vitro. The decreasing of adhesion ability of lung cancer cells by YSV may disturb the process of metastasis, which will inhibit the adhesion of tumor cells 

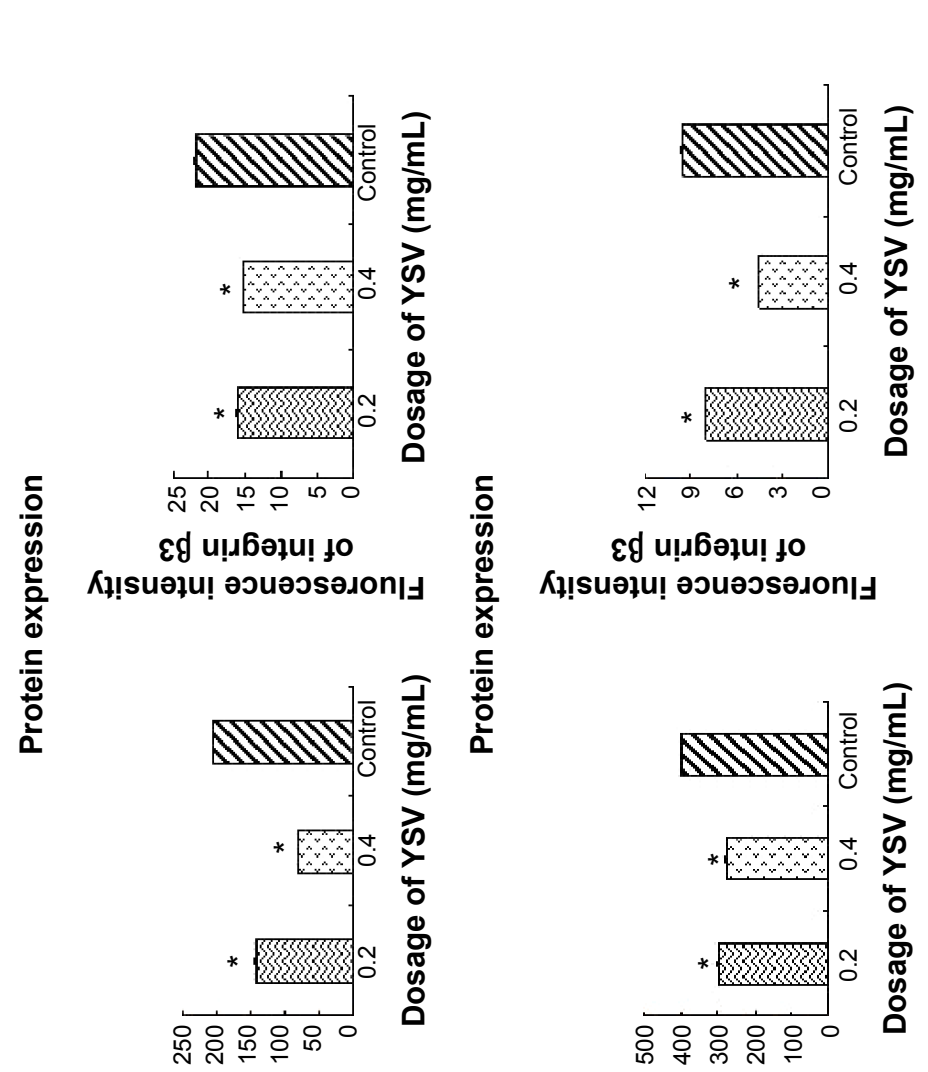

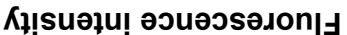

If u! uбәри! to

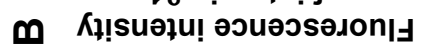

ㅇํำ
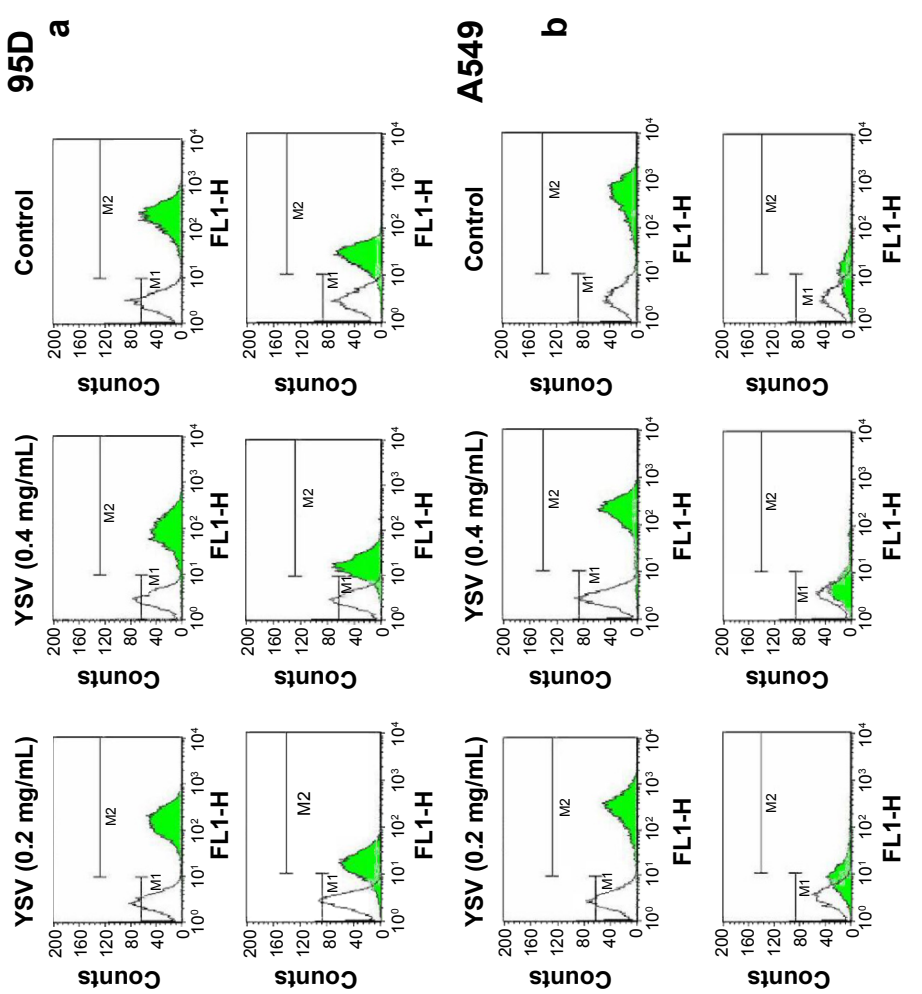

高

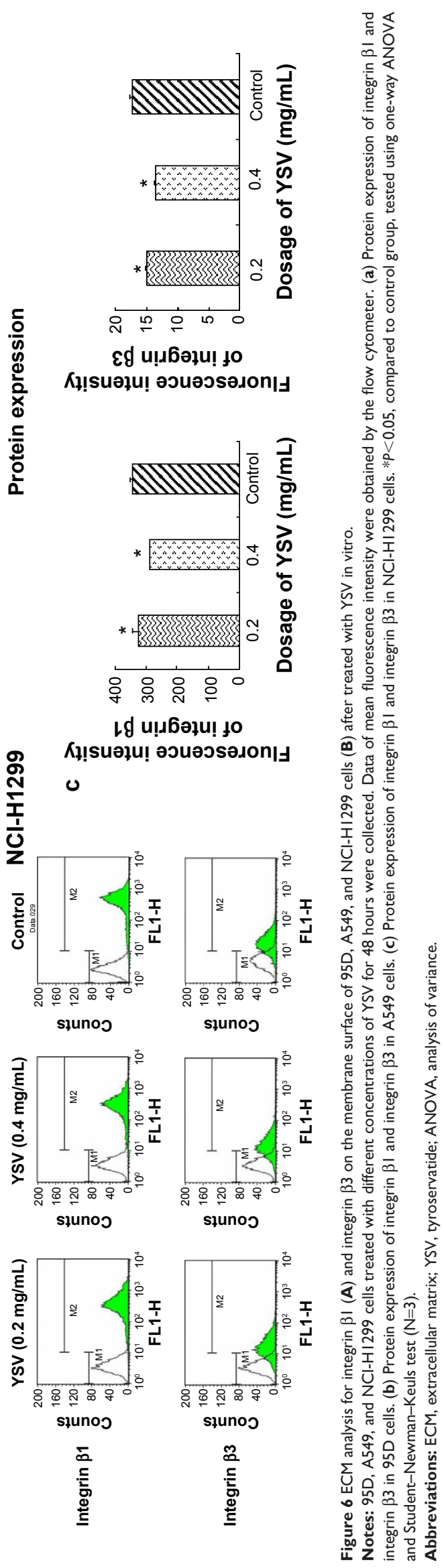


to normal surrounding tissue and blood capillary. In addition, YSV markedly inhibited the invasion of human lung cancer cells 95D, A549, and NCI-H1299. YSV may inhibit the invasion of and damage caused by the tumor cells on the basement membrane (BM), and decrease the ability of tumor cells to penetrate the blood vessel and infiltrate the target organs, which inhibit the long-distance metastasis.

The process of invasion and metastasis by a tumor cell requires the degradation of natural barrier such as ECM or $\mathrm{BM}$ by some protease, including MMPs (matrix MMPs), serine proteinase, and cysteine proteinase. Especially, MMPs are believed to play a vital role in the metastasis of tumor cells through degradation of ECM and other proteins. ${ }^{36}$ In MMPs family, MMP-2 and MMP-9 efficiently degrade collagen IV, thereby assisting the metastatic cancer cells to pass through the BM. ${ }^{37-39}$ YSV markedly reduce the expression and activity of MMP-2 and MMP-9 in human lung cancer cells 95D, A549, and NCI-H1299. The reduction in expression and activity of MMP-2 and MMP-9 by YSV may prevent the tumor cells migration crossing tissue barrier and lower the adhesion of tumor cells. Also, some bioactive factors such as angiogenesis factor and transforming growth factor- $\beta$ induced by MMP- 2 and MMP-9 may be restricted to induce the formation of new blood vessels of tumor.

MMPs production and activity are highly regulated by many factors. Integrin-FAK signaling pathway is an important road to regulate the expression and activity of MMPs. ${ }^{40}$ The activated FAK can facilitate cancer metastasis by increasing the expression and activity of MMP-2 and MMP-9. YSV not only significantly downregulate the mRNA and protein expression of FAK but also decrease the phosphorylation of FAK Tyr397 and FAK Tyr576/577, which means that the activating FAK was reduced. The inhibition of FAK by YSV will decrease the expression and activity of MMP-2 and MMP-9 and disturb the tumor metastasis or invasion.

The integrin family of cell adhesion receptors plays a fundamental role in the processes involved in cell division, differentiation, and movement. The extracellular domains of integrin $\alpha / \beta$ heterodimers mediate cell-matrix and cell-cell contacts, while their cytoplasmic tails associate with the cytoskeleton. Integrins are capable of transducing information in a bidirectional manner, and the $\beta$ subunit is now recognized to play an important role in this process. Integrins $\beta 1$ and $\beta 3$ play vital roles in FAK activation and formation of FAP. YSV markedly inhibited the mRNA and protein expression of integrins $\beta 1$ and $\beta 3$, which disturb the signal transduction to prompt autophosphorylation at FAK Tyr397. Therefore, the downstream effectors of integrinFAK signaling pathway - MMP-2 and MMP-9 - were inhibited to block the adhesion and invasion of tumor cells.

Our data suggested that one mechanism by which YSV may inhibit tumor metastasis is through inhibition of the integrin-FAK signaling pathway. YSV could inhibit the expression of integrins $\beta 1$ and $\beta 3$ to disrupt the FAP formation, resulting in inhibition of phosphorylation at Tyr397 and Tyr576/577 of FAK. Also, YSV could decrease the expression of FAK. The inhibition of expression and activation of FAK by YSV downregulated the expression and activity of MMP-2 and MMP-9, which suppressed the degradation of ECM by tumor cells to interrupt the adhesion and invasion of lung cancer. The anti-metastatic effects of YSV may be as follows: YSV downregulated mRNA level and protein expression of integrin $\beta 1$ and integrin $\beta 3$, reduced the FAK activity and expression, and thus inhibited the integrin-FAK signal transduction, and as a result, the activities and expression of these signal transduction downstream effector molecules MMP-2 and MMP-9 were degraded. Then, the metastatic ability of lung cancer cells reduced. And our previous study suggests that the antitumor effects of YSV might be mediated by its inhibition of histone deacetylase activity. ${ }^{41}$ Reversible modification of the terminal tails of core histones constitutes the major epigenetic mechanism for controlling gene expression. HDAC inhibitors block this action and can result in hyperacetylation of histones, thereby affecting gene expression. ${ }^{42}$ Therefore, we speculated that downregulation of MMPs and integrin-FAK transcription may be affected by acetylation at the chromatin by YSV.

\section{Acknowledgments}

This work was supported by grants from the National Major Scientific and Technological Special Project for "Significant New Drugs Development" (grant number: 2014ZX09101005004), National Basic Research Program (973 Program, People's Republic of China; grant number: 2009CB918903), Natural Science Foundation of Tianjin (grant number: 09JCZDJC19700), PhD Programs Foundation of Ministry of Education of China (grant number: 20101202110001), and Cooperation Project in Industry, Education and Research of Guangdong Province (grant number: 2009B090300430).

\section{Disclosure}

The authors report no conflicts of interest in this work. 


\section{References}

1. Zheng M, Lu R, Che X, et al. Tyroservatide therapy for tumor growth, invasion and metastasis of Lewis lung carcinoma and human lung carcinoma A549. Oncology. 2006;70:418-426.

2. $\mathrm{Fu} \mathrm{Z,} \mathrm{Lu} \mathrm{R,} \mathrm{Jia} \mathrm{J,} \mathrm{et} \mathrm{al.} \mathrm{Inhibition} \mathrm{of} \mathrm{five} \mathrm{xenografted} \mathrm{human} \mathrm{cancers}$ and two murine cancers by the tripeptide tyroservatide. Anticancer Drugs. 2007;18:467-470.

3. Pan ST, Zhou ZW, He ZX, et al. Proteomic response to 5,6-dimethylxanthenone 4-acetic acid (DMXAA, vadimezan) in human non-small cell lung cancer A549 cells determined by the stable-isotope labeling by amino acids in cell culture (SILAC) approach. Drug Des Devel Ther. 2015;9:937-968.

4. Kawai H, Kiura K, Tabata M, et al. Characterization of non-small-cell lung cancer cell lines established before and after chemotherapy. Lung Cancer. 2002;35:305-314.

5. Che XC, Lu R, Hu JX, et al. Inhibitory effect of tripeptide compound tyroservaltide on invasion and metastasis of mouse melanoma cell line B16-F10. Ai Zheng. 2006;25:275-280.

6. Onn A, Isobe T, Itasaka S, et al. Development of an orthotopic model to study the biology and therapy of primary human lung cancer in nude mice. Clin Cancer Res. 2003;9:5532-5539.

7. ATCC. NCI-H1299. Available from: http://www.atcc.org/Products/ All/CRL-5803.aspx. 1992.

8. Lu YL. Spontaneous metastasis of clonal cell subpopulations of human lung giant cell carcinoma after subcutaneous inoculation in nude mice. Zhonghua Zhong Liu Za Zhi. 1989;11:1-7.

9. Clezardin P. Recent insights into the role of integrins in cancer metastasis. Cell Mol Life Sci. 1998;54:541-548.

10. Liu D, Pearlman E, Diaconu E, et al. Expression of hyaluronidase by tumor cells induces angiogenesis in vivo. Proc Natl Acad Sci US A. 1996; 93:7832-7837.

11. Kurizaki T, Toi M, Tominaga T. Relationship between matrix metalloproteinase expression and tumor angiogenesis in human breast carcinoma. Oncol Rep. 1998;5:673-677.

12. Nagase H, Woessner JF. Matrix metalloproteinases. J Biol Chem. 1999; 274:21491-21494.

13. Määttä M, Santala M, Soini Y, Talvensaari-Mattila A, TurpeenniemiHujanen T. Matrix metalloproteinases 2 and 9 and their tissue inhibitors in low malignant potential ovarian tumors. Tumour Biol. 2004;25: 188-192.

14. Papathoma AS, Petraki C, Grigorakis A, et al. Prognostic significance of matrix metalloproteinases 2 and 9 in bladder cancer. Anticancer Res. 2000;20:2009-2013.

15. Hu B, Jarzynka MJ, Guo P, Imanishi Y, Schlaepfer DD, Cheng SY. Angiopoietin 2 induces glioma cell invasion by stimulating matrix metalloprotease 2 expression through the alphavbeta1 integrin and focal adhesion kinase signaling pathway. Cancer Res. 2006;66:775-783.

16. Donejko M, Przylipiak A, Rysiak E, Głuszuk K, Surażyński A. Influence of caffeine and hyaluronic acid on collagen biosynthesis in human skin fibroblasts. Drug Des Devel Ther. 2014;8:1923-1928.

17. Schaller MD. Biochemical signals and biological responses elicited by the focal adhesion kinase. Biochim Biophys Acta. 2001;1540:1-21.

18. Weiner TM, Liu ET, Craven RJ, Cance WG. Expression of focal adhesion kinase gene and invasive cancer. Lancet. 1993;342:1024-1025.

19. Owens LV, Xu L, Craven RJ, et al. Overexpression of the focal adhesion kinase (p125FAK) in invasive human tumors. Cancer Res. 1995;55: 2752-2755.

20. Rovin JD, Frierson HF Jr, Ledinh W, Parsons JT, Adams RB. Expression of focal adhesion kinase in normal and pathologic human prostate tissues. Prostate. 2002;53:124-132.

21. Lark AL, Livasy CA, Calvo B, etal. Overexpression of focal adhesion kinase in primary colorectal carcinomas and colorectal liver metastases: immunohistochemistry and real-time PCR analyses. Clin Cancer Res. 2003;9: 215-222.
22. Tie GD, Cao JJ, Zhao XX, Duan AK. Fibronectin-Integrin interaction start of matrix metalloproteinase activity in the blastocyst. Chin Sci Bull. 2000:45:475-479.

23. de Melker AA, Sonnenberg A. Integrins: alternative splicing as a mechanism to regulate ligand binding and integrin signaling events. Bioessays. 1999;21:499-509.

24. Livak KJ, Schmittgen TD. Analysis of relative gene expression data using real-time quantitative PCR and the 2(-Delta Delta C (T)). Methods. 2001;25:402-408.

25. Yuan LX, He MW, Zhang B, Xie KS, Tang WY. Is the expression of MMP-2, MMP-9, and TIMP-2 related to metastasis and recurrence of breast cancer? Tumor. 2002;22:294-296.

26. Aznavoorian S, Murphy AN, Stetler-Stevenson WG, Liotta LA. Molecular aspects of tumor cell invasion and metastasis. Cancer. 1993;71: $1368-1383$

27. Chen HC, Appeddu PA, Isoda H, Guan JL. Phosphorylation of tyrosine 397 in focal adhesion kinase is required for binding phosphatidylinositol 3-kinase. J Biol Chem. 1996;271:26329-26334.

28. Zhang X, Chattopadhyay A, Ji QS, et al. Focal adhesion kinase promotes phospholipase C-gamma1 activity. Proc Natl Acad Sci US A. 1999;96: 9021-9026.

29. Calalb MB, Polte TR, Hanks SK. Tyrosine phosphorylation of focal adhesion kinase at sites in the catalytic domain regulates kinase activity: a role for Src family kinases. Mol Cell Biol. 1995;15:954-963.

30. Hsia DA, Mitra SK, Hauck CR, et al. Differential regulation of cell motility and invasion by FAK. J Cell Biol. 2003;160:753-767.

31. Tamura M, Gu J, Danen EH, Takino T, Miyamoto S, Yamada KM. PTEN interactions with focal adhesion kinase and suppression of the extracellular matrix-dependent phosphatidylinositol 3-kinase/Akt cell survival pathway. J Biol Chem. 1999;274:20693-20703.

32. Hood JD, Cheresh DA. Role of integrins in cell invasion and migration. Nat Rev Cancer. 2002;2:91-100.

33. Liu S, Calderwood DA, Ginsberg MH. Integrin cytoplasmic domainbinding proteins. J Cell Sci. 2000;113:3563-3571.

34. Burridge K, Chrzanowska-Wodnicka M, Zhong C. Focal adhesion assembly. Trends Cell Biol. 1997;7:342-347.

35. Dedhar S, Hannigan GE. Integrin cytoplasmic interactions and bidirectional transmembrane signalling. Curr Opin Cell Biol. 1996;8: 657-669.

36. Li WP, Anderson CJ. Imaging matrix metalloproteinase expression in tumors. Q J Nucl Med. 2003;47:201-208.

37. Ren F, Fan M, Mei J, et al. Interferon- $\gamma$ and celecoxib inhibit lung-tumor growth through modulating M2/M1 macrophage ratio in the tumor microenvironment. Drug Des Devel Ther. 2014;8:1527-1538.

38. Musso O, Théret N, Campion JP, et al. In situ detection of matrix metalloproteinase-2 (MMP2) and the metalloproteinase inhibitor TIMP2 transcripts in human primary hepatocellular carcinoma and in liver metastasis. J Hepatol. 1997;26:593-605.

39. Rha SY, Kim JH, Roh JK, et al. Sequential production and activation of matrix-metalloproteinase-9 (MMP-9) with breast cancer progression. Breast Cancer Res Treat. 1997;43:175-181.

40. Segarra M, Vilardell C, Matsumoto K, et al. Dual function of focal adhesion kinase in regulating integrin-induced MMP-2 and MMP-9 release by human T lymphoid cells. FASEB J. 2005;19:1875-1877.

41. Zhu Z, Jia J, Lu R, et al. Expression of PTEN, p27, p21 and AKT mRNA and protein in human BEL-7402 hepatocarcinoma cells in transplanted tumors of nude mice treated with the tripeptide tyroservatide (YSV). Int J Cancer. 2006;118:1539-1544.

42. Ropero S, Esteller M. The role of histone deacetylases (HDACs) in human cancer. Mol Oncol. 2007;1:19-25. 


\section{Publish your work in this journal}

Drug Design, Development and Therapy is an international, peerreviewed open-access journal that spans the spectrum of drug design and development through to clinical applications. Clinical outcomes, patient safety, and programs for the development and effective, safe, and sustained use of medicines are a feature of the journal, which has also been accepted for indexing on PubMed Central. The manuscript management system is completely online and includes a very quick and fair peer-review system, which is all easy to use. Visit http://www.dovepress.com/testimonials.php to read real quotes from published authors.

Submit your manuscript here: http://www.dovepress.com/drug-design-development-and-therapy-journal 